\title{
Customer RPE: Using customer performance to filter noise out of CEO incentive contracts
}

\author{
Mary Ellen Carter \\ Carroll School of Management \\ Boston College \\ maryellen.carter@bc.edu \\ Jen Choi \\ Goizueta Business School \\ Emory University \\ jen.choi@emory.edu \\ Karen L. Sedatole* \\ Goizueta Business School \\ Emory University \\ ksedatole@emory.edu
}

July 2020

\begin{abstract}
We thank Ewelina Forker, Susanna Gallani, Tatiana Sandino, Zac Wiser, and Jake Zureich and workshop participants at Emory University, Harvard Business School, KAIST Business School, Arizona State University, and Executive Compensation and Corporate Governance Brownbag Series for helpful comments on an earlier version of this paper. We acknowledge the financial support of Emory University and Boston College.
\end{abstract}

* Corresponding author

***Preliminary draft: Please do not cite or distribute without authors' permission. 


\title{
Customer RPE: Using customer performance to filter noise out of CEO incentive contracts
}

\begin{abstract}
The "informativeness criterion" (Holmstrom 1982) states that any information item that is informative about a CEO's effort be used in incentive contracting. Prior research documents negative incentive weights on industry peer performance in CEO contracting in what is known as "relative performance evaluation" (RPE). RPE improves the efficiency of incentive contracting by filtering noise from CEO performance measurement. We test whether the performance of a firm's customer base is also used to improve incentive contracting, what we term "customer relative performance evaluation" (customer RPE). Consistent with customer RPE, we document a negative incentive weight on customer performance in CEO incentive contracts incremental to the negative incentive weight on performance of industry peers documented in prior research. Further, the negative incentive weight on customer performance is larger in absolute value for firms whose performance is more highly correlated with their customers' performance, when the firm's products/services are more specialized, and when the firm has lower operating flexibility. Moreover, the weight on customer performance decreases when the adverse incentives triggered by customer RPE are more costly.
\end{abstract}




\section{INTRODUCTION}

Relative performance evaluation (RPE) refers to the use of peer performance, in addition to firm performance, in evaluating a CEO. By using peer performance, a firm can assess exogenous shocks that are shared with its peers and remove these shocks for evaluation purposes. A key decision in the implementation of RPE is the selection of peer firms against which performance is compared. Indeed, a challenge of implementing RPE is identifying peers that share common noise with the firm (Gibbons and Murphy 1990). Prior studies find that firms use market indices to filter out economy-wide shocks, or other firms in the same industry to remove industry-wide shocks (Rajgopal et al. 2006; Albuquerque et al. 2009). In this paper, we extend prior RPE research to examine the extent to which firms incorporate the performance of their unique customer base into RPE, what we term "customer RPE."

We contend that using customers as RPE peers enables the firm to filter out demand shocks that are transmitted to the firm from its downstream trading partners. Shocks to the firm's customer base, as opposed to shocks common to the customer industry as a whole, are not likely to be a source of common noise in industry peer performance and thus cannot be filtered by using industry peers or market indices. Also, while idiosyncratic performance shocks of industry peers are, by definition, uninformative about the firm's performance and thus undermines the incentive risk reduction role of industry peer RPE (Wu 2013; Wu 2017), idiosyncratic shocks to a customer's performance are relevant to CEO incentive risk reduction because those shocks transfer up the supply chain to affect the firm's own performance. Using customers as RPE peers thus enables the firm to filter out exogenous shocks in a more precise and comprehensive manner, making customer RPE incrementally valuable over industry peer RPE examined in prior research as a means of filtering noise from CEO performance and improving incentive contracting efficiency. 
While recent research examining RPE peer disclosures documents that 40 percent of disclosed peers do not belong in the same two-digit industry group as the firm (Gong et al. 2011), it has not explicitly examined the nature of the firms comprising that 40 percent. Indeed, in our sample, we find that 21 percent of firms disclosing the explicit use of RPE in their proxy statements name at least one customer as an RPE peer.

We identify a firm's customers using the Supply Chain Relationship data from FactSet, which maps the supply chain partners of firms with data sourced from 8-K/10-K regulatory filings, press releases, corporate action releases, and company websites. Using these data, we examine the extent to which customer performance affects CEO compensation using the so-called "implicit" (or indirect) RPE test in which RPE is inferred from a negative incentive weight on peer performance (either industry peer performance or, the focus of our study, customer performance) in CEO compensation. The indirect test of RPE is more comprehensive than analyzing RPE peers disclosed in proxy statements because firms selectively disclose RPE peers (Faulkender and Yang 2010; Gong et al. 2011) and actual relative performance evaluation use may be larger than what firms report in the proxy statements (Black, Dikolli, and Hofmann 2015).

We find a negative compensation incentive weight on mean customer performance, consistent with customer RPE and the use of customer performance to insulate the effect of downstream demand shocks on firm performance. This negative incentive weight on customer performance is incremental to the negative incentive weight on industry-size peers (firms in the same 2-digit SIC code and size quartile, as defined in Albuquerque 2009) and the market index (S\&P 500 index), and is robust to CEO- or firm-fixed effects.

Because the informativeness of peer group performance is critical to the ability of RPE to mitigate contracting risk and improve contracting efficiency (Holmstrom 1982), we next examine 
whether the use of customer RPE varies with proxies for the extent to which shocks to customer performance transfer to the firm - that is, the degree of common risk. In cross-sectional tests, we document a larger negative incentive weight on customer performance when the correlation of stock returns between the focal firm and its customers is larger. We also find a larger negative incentive weight for firms whose product/service offerings are more specialized. These firms are more likely to be tied to their customers and are more vulnerable to shocks that their customers face. Lastly, we posit that firms vary in their ability to adapt to performance shocks. Firms that are less affected by demand shocks have less need/benefit from insulating CEO compensation from those shocks. Consistent with this, we find a less negative incentive weight for firms that have greater cost elasticity.

One challenge of including customers in the RPE peer group is that it may motivate CEOs to engage in short-term strategic interactions that have longer term negative consequences for value creation, not only for the firm itself, but for the entire value chain. That is, because RPE means improved performance of a customer peer firm negatively influences CEO compensation, customer RPE creates incentives for CEOs to engage in more aggressive strategic behaviors with its downstream partners (e.g., price gouging).

We examine whether the negative incentive weight on customer performance in CEO incentive contracting is weaker when cooperation with the customer is more beneficial to the firm. In our second set of cross-sectional tests, we use customer base concentration (indicating a more profitable relationship, Patatoukas 2011) and future relationship duration as proxies for the value of cooperation and the need to dampen aggressive strategic actions with the customer. We find that higher customer base concentration and longer future relationship duration lead to a smaller negative incentive weight on customer performance. 
To rule out the concern that some common factor affects both the customer's performance and the focal firm's compensation but is not related to the use of customer RPE, we examine the relation using non-customer performance. That it, we examine the incentive weight on the performance of the firm's customers in the year prior to them becoming a customer and in the year after they cease being a customer. If our findings were due to some other factor related to the customer-firm match, we would expect to see the negative incentive weight we document in these pre- and post-relationship periods. Affirming our evidence of customer RPE, we find no incentive weight on customer performance for these inactive customer relationships. Moreover, we examine major natural disasters to customer headquarters (Barrot and Sauvagnat 2016) to examine the effect of exogenous demand shocks and find robust results.

Our research contributes to the literature by broadening the scope of relative performance evaluation, a line of inquiry that has gained considerable attention from accounting, finance, and economics researchers (Bertrand and Mullainathan 2001, Jenter and Kanaan 2015, Jayaraman et al. 2018). While previous studies have been limited to examining firm's industry competitors or market indices as RPE peers, we examine the role of a firm's customers as RPE peers. We show that customer relative performance evaluation provides an additional lever not previously documented by which firms filter noise from performance measures and reduce incentive contracting risk. Moreover, our results show that the incentive weight on customer peer performance has different determinants from that on industry peer performance. For example, tournament theory suggests that more specialized firms would put less weight on industry peer performance because the similarity of the firm to its competitor peers is low (e.g. Lazear and Rosen 1981, Albuquerque 2013). In contrast, in this study we show that more specialized firms put more weight on customer peer performance. Finally, we provide evidence of the trade-offs firms face 
when incorporating customer performance into RPE. Firms forego the noise-filtering benefits of customer RPE when cooperation with the customer, or de-escalation of aggressive behavior against the customer, is of value to the focal firm. Thus, our study contributes to the growing body of research on the determinants of RPE peer group composition and the consequences of such choices.

\section{PRIOR LITERATURE AND HYPOTHESIS DEVELOPMENT}

The "informativeness criterion" (Holmstrom 1982) argues that any information item that is informative about CEO effort should be used in incentive contracting. Consistent with this criterion, relative performance evaluation (RPE) refers to the use of peer performance, in addition to own-firm performance, in evaluating a CEO's efforts. Under RPE, common exogenous shocks that are shared by both a firm and its peers can be filtered out from the firm's performance by controlling for peer performance in determining compensation. By implementing RPE, a firm can increase the precision of performance measurement, sheltering the CEO from performance effects beyond his control, and thus increase the efficiency of CEO compensation contracts (Lazear and Rosen 1981; Holmstrom 1982).

Given the theoretical benefit of RPE, prior research has empirically examined its use in compensation contracting. Bannister et al. (2011) document that 30\% of the S\&P 500 firms explicitly acknowledge the use of RPE in their proxy statements, while Gong et al. (2011) find that $25 \%$ of the S\&P 1500 firms explicitly disclose their use of RPE in their proxy statements after the SEC 2006 disclosure rule. Furthermore, consistent with Antle and Smith (1986) who state that firms use RPE without explicitly disclosing so, Albuquerque (2009) documents a negative association between CEO compensation and industry-size peer performance across firms in the CRSP/Compustat-Merged sample. 
A key decision in the implementation of RPE is the selection of peer firms against which performance is compared. Indeed, a challenge of implementing RPE is identifying peers that share common noise with the firm (Gibbons and Murphy 1990). Assuming that firms use RPE to filter out economy-wide or industry-wide shocks, prior studies have focused on the use of market indices (e.g. Hall and Liebman 1998) or industry peers (e.g. Gibbons and Murphy 1990) as RPE peers. ${ }^{1}$ However, a firm's specific and unique supply chain also imposes performance risk in the form of demand shocks transferred to the firm from its downstream trading partners (Olsen and Dietrich 1985; Cohen and Frazzini 2008; Cheng and Eshleman 2014). Ball Corporation, a major metal packaging company in the U.S., writes in their 2017 10-K (p. 8): "The primary customers for our aerospace segment are U.S. government agencies or their prime contractors. Our contracts with these customers are subject to several risks, including funding cuts and delays, technical uncertainties, budget changes, competitive activity and changes in scope." That is, Ball Corporation's performance is exposed to external shocks transferred from its customers that are not necessarily associated with the CEO's actions, and that do not necessarily affect Ball's competitors who do not share their customer base.

Shocks to customer demand may derive from exogenous events impacting the customers themselves (e.g. government funding cuts for Ball Corporation's customers), or deliberately induced by the customers (e.g. marketing promotions). Neither of these types of downstream demand shocks are informative regarding the focal firm CEO's efforts and, hence, their effects should be filtered from his incentive contract. Importantly, these demand shocks cannot be completely filtered out by RPE using only market or industry peers unless these peers share the same customer base. Also, while filtering idiosyncratic performance shocks of industry peers from

\footnotetext{
1 "Industry peers" refers to other firms in the same industry defined as 1- to 4-digit SIC code (e.g. Gibbon and Murphy 1990, Garvey and Milbourn 2006, Albuquerque 2009) or 6-digit GICS codes (e.g. Albuquerque 2014).
} 
firm performance do not enhance the efficiency of CEO compensation contracts (Wu 2013; Wu 2017), filtering idiosyncratic shocks to a customer's performance are relevant to CEO incentive risk reduction because those shocks transfer up the supply chain to affect the firm's own performance.

As an example, a warehouse fire at a competitor peer firm (i.e., an idiosyncratic performance shock) would reduce that competitor firm's performance. If the focal firm was using customer RPE, The focal firm's own CEO would benefit from this negative performance shock to his RPE peer with higher compensation despite the fact that the competitor firm's idiosyncratic performance shock was uninformative about the CEO's effort. But a warehouse fire at a customer peer firm, although idiosyncratic in nature, would potentially negatively impact the focal firm's performance and, hence, be informative in assessing its CEO (i.e., the CEO should not be penalized for a decline in performance due to the fire).

As a result, including customers as RPE peers, in addition to market or industry peers, provides the firm with an incrementally precise performance measure of CEO efforts. Thus, in addition to filtering out market and industry shocks by the inclusion of indices or similar peer firms, we predict that focal firms will incorporate customer RPE into CEO incentive contracting; that is, that there will be a negative association between CEO compensation and the performance of the firm's customer base. However, not all shocks transmitted from customers are exogenous to CEO efforts. For example, increased sales of a customer could be due to higher quality products supplied by the firm, and selecting well-performing customers may be related to CEO's negotiation efforts. If the CEO is not compensated for these efforts by his or her rewards from higher firm performance (e.g. compensation from higher stock prices), filtering out customer shocks from firm performance would increase precision (by filtering out exogenous shocks) at 
the expense of sacrificing sensitivity (by filtering out shocks related to CEO efforts). Facing this tradeoff, firms might refrain from using customers as RPE peers.

\section{H1: CEO compensation is negatively associated with the performance of the firm's customer base.}

The theory underlying the value of RPE is that any information item that is informative about CEO effort will be incorporated into an optimal incentive contract to improve incentive contracting efficiency (Holmstrom 1982). Peer performance, whether it be industry peer or customer peer, is informative about the focal firm CEO's efforts when the firm and its peers are both affected by "common shocks." Including peer performance into incentive contracting provides a means of filtering common shocks from the CEOs performance measure, thereby providing the firm with a more precise measure of CEO performance (e.g., Banker and Datar 1989). Empirical RPE research measures the degree of noise-filtering benefit - that is, the informativeness of peer performance - by the extent to which peer performance and focal firm performance covaries. Studies examining industry peer RPE document larger negative compensation incentive weights on industry peer performance when the correlation between focal firm and peer firm

performance is larger (Gong et al. 2011; Albuquerque 2014). Further, firms are more likely to disclose the use of industry peer RPE when this correlation is higher (i.e., when there is more "common risk"), and are more likely to choose specific peers with "higher common-risk-reduction ability" (Gong et al. 2011). Accordingly, we expect greater use of customer RPE as the correlation of firm performance and the performance of its customer base increases. Stated formally:

\section{H2a: The negative association between CEO compensation and the performance of the firm's customer base is larger in magnitude when customer and focal firm performance are more highly correlated.}

Customer RPE provides valuable noise-filtering and compensation risk-reducing benefits. However, basing pay on performance relative to a customer means higher customer performance 
leads to lower CEO pay (a negative pay-for-performance sensitivity for customer performance). This creates incentives for the CEO to take strategic actions to reduce the performance of RPE peers (see, for example, Gong et al. 2011). Industry peer RPE research finds evidence of more aggressive strategic actions against competitors, especially when there is bilateral RPE induced by overlapping RPE peer groups (i.e., pairs of industry competitor firms that select each other as RPE peers) (Feichter, Moers and Timmermans 2019). Other research finds evidence of weaker competitor firm RPE in settings in which strategic interactions is not beneficial. Vrettos (2011) documents negative incentive weights on the performance of industry firm peers who are strategic rivals in the airline industry, but not for industry peers who are strategic partners. Aggarwal and Samwick (1999) find that RPE use is lower overall in industries that are already highly competitive. Both studies suggest that firms sometimes forego noise-filtering benefits of RPE when there is a desire to soften product market competition. While some efforts in this regard are desirable (e.g., aggressive pricing to capture a larger share of the supply chain profits), excessive strategic actions against customers could undermine customer relationships and signal to the customer base the firm's positioning of itself as an adversary instead of as a collaborative upstream partner. A degradation of the supplier-customer relationship can have long-term negative effects on the value of the firm and on the overall supply chain (e.g. Irvine et al. 2015). Thus, we predict that the use of customer RPE will be attenuated in settings in which expected value of supplier-customer relationship is higher. This leads to our second cross-sectional prediction:

H2b: The negative association between CEO compensation and the performance of the firm's customer base is lower in magnitude when customer value is larger to the firm.

\section{DATA AND RESEARCH DESIGN}

We form our initial sample from our process of identifying data availability of customers 
specific to a firm from Supply Chain Relationship data provided by FactSet. These data cover around 23,400 global firms and contains information of firms' supply chain partners. FactSet collects firm information from firm $8-\mathrm{K} / 10-\mathrm{K}$ regulatory filings (including primary customer disclosures mandated by the SEC), company websites, press releases, and corporate action releases dating back to 2003. Note that the FactSet customer identifications include, but are broader than, the major customer data from Compustat Segment files which had been the primary data source in prior studies (e.g. Patatoukas 2011). We retrieve executive compensation data from Execucomp, stock price data from CRSP, and accounting data from Compustat. Our beginning sample size is 31,087 CEO-year observations for the period 2003 to 2018.

Our hypothesis $\mathrm{H} 1$ predicts that firms will use customer RPE. We test for the use of customer RPE using the implicit approach in which we infer customer RPE from a negative incentive weight on customer performance in a regression with CEO pay as the dependent variable. Importantly, we test for customer RPE incremental to industry peer firm RPE. To test hypothesis H1, we estimate the following model following previous studies (e.g. Albuquerque 2009, Albuquerque 2013, Jayaraman et al. 2018):

CEOPay $_{i t}=\beta_{0}+\beta_{1}$ CustPerf $_{i t}+\beta_{2}$ PeerPerf $_{i t}+\beta_{3}$ FirmPerf $_{i t}+<$ ControlVariables $_{i t}>$ $+\varepsilon_{i t}$

The subscript $t$ indicates the fiscal year while the subscript $i$ represents the firm, and standard errors are clustered by firm. Industry and year fixed effects are included. Industries are defined by 2-digit SIC codes.

\subsection{Variable descriptions}

\subsubsection{Dependent Variable}

Our dependent variable, CEO compensation $\left(\right.$ CEOPay $\left.y_{i t}\right)$, is defined as the log of total 
annual flow compensation, which is the sum of salary, bonus, the fair value of stock option awards and restricted stock awards (per SFAS 123R), the change in deferred compensation, non-equity incentive plan compensation, and all other compensation. Consistent with prior literature (Albuquerque 2009; Gong et al. 2011), we take the natural logarithm to mitigate skewness in CEO compensation. We do not include in $C E O P a y_{i t}$ the changes in value of existing firm options and stock holdings owned by the CEO that were granted in prior years, as these changes are mechanically related to firm performance (Albuquerque 2009) and customer performance (Cohen and Frazzini 2008; Eshleman and Guo 2014).

\subsubsection{Independent Variables}

We measure the incentive weights on four measures of performance: firm performance, mean industry peer performance, mean customer performance, and market performance (used in a robustness test). Firm performance $\left(\right.$ FirmPerf $\left.f_{i t}\right)$ is the natural logarithm of one plus annual stock return of the focal firm during the fiscal year. The coefficient on this variable is expected to be positive as $\mathrm{CEO}$ compensation will be increasing in the firm's own performance (i.e., $\beta_{3}>0$ in equation (1)). Peer performance (PeerPerf $\left.f_{i t}\right)$ is the natural logarithm of one plus equal-weighted average of the annual stock return of the firm's industry-size peers (i.e., peer firms in the same 2digit SIC code and size quartile) in year $t$, following Albuquerque (2009). Consistent with prior research documenting the use of industry peer RPE (Albuquerque 2009), we expect the coefficient on PeerPerf $f_{i t}$ to be negative (i.e., $\beta_{2}<0$ in equation (1)). In a robustness test, we include market performance, $M k t P e r f_{t}$, computed as the $\mathrm{S} \& \mathrm{P} 500$ market index return for year $\mathrm{t}$.

Customer performance (CustPerf it $_{\text {) }}$, our primary independent variable of interest, is the natural logarithm of one plus equal-weighted average of the annual stock returns of firm $i$ 's 
customers (as identified in the FactSet database) in year $t .{ }^{2}$ To avoid overlapping firms in CustPerf $_{i t}$ and PeerPerf $f_{i t}$, we omit from PeerPerf $f_{i t}$ the annual returns of the firm's industrysize peers that are also identified as the firm's customers ${ }^{3}$. It is important to note that we are examining the effect of CustPerf $f_{i t}$ after controlling for FirmPerf $f_{i t}$. If customer performance related to CEO efforts (e.g. selecting well-performing customers) is already reflected in firm's stock returns, the coefficient on $\operatorname{CustPerf}_{i t}$ would represent the effect after controlling for that CEO-effort-related customer performance. Also, controlling for industry peer RPE (PeerPerf $\left.f_{i t}\right)$, the coefficient on CustPerf $_{\text {it }}$ represents noise-filtering that is incremental to industry peer RPE observed in prior studies (e.g. Albuquerque 2009). If firms use customer RPE as our hypothesis $\mathrm{H} 1$ predicts, $\mathrm{CEO}$ compensation will be negatively associated with average customer performance, $\beta_{1}<0$

Hypothesis $\mathrm{H} 2 \mathrm{a}$ predicts that the negative association between CEO total compensation and customer performance will be larger in magnitude when customer and focal firm performance are more highly correlated. To test this prediction, we calculate the correlation between firm performance $\left(\right.$ FirmPerf $\left._{i t}\right)$ and average customer performance from year t-4 to $\mathrm{t}\left(\operatorname{Corr}_{i t}\right)$, and interact this variable with customer performance $\left(\operatorname{CustPerf}_{i t}\right)$. We use the correlation of annual returns because our CEOPay $y_{i t}$ measures the annual flow compensation. All interacted variables are mean-centered to facilitate interpretation and to alleviate multi-collinearity (Aiken and West 1991). Requiring 5-year returns for both the firm and the customer groups leads to a loss of 4,749 observations. To test Hypothesis H2a we estimate the following model:

$$
\text { CEOPay }_{i t}=\beta_{0}+\beta_{1} \text { CustPerf }_{i t}+\beta_{2} \operatorname{Corr}_{i t}+\beta_{3} \text { CustPerf }_{i t} * \operatorname{Corr}_{i t}+\beta_{4} \text { PeerPerf }_{i t}+
$$

\footnotetext{
${ }^{2}$ Results are robust when we require the customer to have a relationship with firm $i$ that lasts more than 6 months during year $\mathrm{t}$.

${ }^{3}$ Results are robust to the inclusion of overlapping customer and industry peers or omitting the overlapping firms from CustPerfit.
} 
$\beta_{5}$ FirmPerf $_{i t}+<$ ControlVariables $_{i t}>+\varepsilon_{i t}$

Hypothesis $\mathrm{H} 2 \mathrm{a}$ predicts that $\beta_{3}<0$ indicating a stronger customer RPE effect for firms in which the correlation between firm performance and customer performance is larger. As before, standard errors are clustered by firm. Industry and year fixed effects are included. Industries are defined by 2-digit SIC codes.

Hypothesis $\mathrm{H} 2 \mathrm{~b}$ predicts that the negative association between $\mathrm{CEO}$ total compensation and customer performance will be smaller in magnitude when customer value is higher to the firm. Although using customer RPE has the benefit of insulating demand shocks, this practice can also motivate the CEO to take strategic actions (e.g., price gouging) harmful to the long-term relationship with the customer and, ultimately, harmful to long-term firm value.

We use two proxies for customer value: customer-base concentration and average future duration of the customer relationships. Patatoukas (2011) finds that more concentrated customer relationships are more profitable for firms because of efficiency gains. In addition, all else equal, customer relationships with longer future durations would bring higher total profit to the firm. ${ }^{4}$ Customer-base concentration, $\left(C C_{-} R a n k_{i t}\right)$, is defined as in Patatoukas (2011) as the decile rank of the sum of customers' squared sales percentages. ${ }^{5}$ The average future duration of the firm's customer relationships is $F_{-}$duration ${ }_{i t}$. Future customer relationship duration for each customer is defined by the number of days between two dates: the first day of year $t$ (or the start-date of the relationship, whichever comes later) and the second date is the end-date of the firm's final

\footnotetext{
${ }^{4}$ A concentrated customer base also exposes the firm to greater risk due to lack of diversification. While we predict that the firm will decrease the negative incentive weight on customer performance to temper excessive strategic behaviors, a smaller negative incentive weight could also be interpreted to be the firm's efforts to motivate the CEO to take actions to mitigate risk imposed by a concentrated customer base. It is also possible the board will increase the negative incentive weight to reduce the risk exposure in the CEO incentive contract, which would bias us against finding our predicted result.$$
{ }_{5} C C_{i t}=\sum_{j=1}^{J}\left(\text { Sales }_{i j t}\right)^{2} \text {. }
$$ 
relationship with the customer.

To test Hypothesis H2a we estimate the following model:

CEOPay $_{i t}=\beta_{0}+\beta_{1}$ CustPerf $_{i t}+\beta_{2}<$ customer value $_{i t}+\beta_{3}$ CustPerf $_{i t} *$

$<{\text { customer value }>_{i t}+\beta_{4} \text { PeerPerf }}_{i t}+\beta_{5}$ FirmPerf $_{i t}+<$ ControlVariables $_{i t}>+\varepsilon_{i t}$

where <customer value> is either $C C_{-} R a n k_{i t}$ or $F_{-}$duration $_{i t}$. All interacted variables are meancentered to facilitate interpretation and to alleviate multi-collinearity. Hypothesis $\mathrm{H} 2 \mathrm{~b}$ predicts that $\beta_{3}>0$ indicating a weaker customer RPE effect for firms in which customer value is greater. As before, standard errors are clustered by firm and 2-digit industry and year fixed effects are included.

\subsubsection{Control Variables}

Following prior literature, we control for focal firm stock return volatility $\left(\operatorname{Vol}_{i t}\right)$, measured as the standard deviation of the monthly stock returns during year $\mathrm{t}$, and leverage $\left(\operatorname{Lev}_{i t}\right)$, defined as the book value of liability divided by the book value of assets. We also control for firm size $\left(\right.$ Lnat $\left._{i t}\right)$ measured as the logarithm of assets, growth opportunities $\left(B t m_{i t}\right)$, measured as the book value of equity divided by the market value of equity, and an indicator variable for whether the CEO serves as the chairman of the board (Duality ${ }_{i t}$ ) during year $\mathrm{t}$. We further control for CEO tenure (LnCEOtenure ${ }_{i t}$ ) measured as the logarithm of the full years the CEO has been in office until year $t$, and the sum of the value of stock and equity portfolio held by the CEO, also known as inside equity (Firmspecificwealth $h_{i t}$ ) (Coles et al. 2006). All continuous variables are winsorized at 1 percent (top and bottom). Variable definitions are in Appendix A.

Omitting observations with missing data for any of our variables results in a final sample of 11,662 CEO-year observations from 1,735 firms from 2003 to 2018. The sample selection procedure is provided in detail in Table 1. 


\section{<Insert Table 1 about here>}

\section{RESULTS}

\subsection{Descriptive Statistics}

Table 2 provides the descriptive statistics for the sample. The mean (median) value of logged total annual flow compensation $\left(\right.$ CEOPay $\left._{i t}\right)$ is 8.23 (8.30). In raw values, the mean (median) value of total annual flow compensation is 5.79 million (4.03 million) dollars. The mean (median) value of firms' logged annual stock return $\left(\right.$ FirmPerf $\left._{i t}\right)$ is $0.07(0.11)$. The mean (median) value of customers' logged annual stock return $\left(\right.$ CustPerf $\left._{i t}\right)$ is $0.10(0.12)$, while the mean (median) value of industry-size peers' logged annual return $\left(P e e r P e r f_{i t}\right)$ is $0.10(0.12)$.

Following prior research, we form an industry peer group to compute PeerPerf $f_{i t}$ based on SIC 2-digit industry codes and size quartiles. For our customer performance variable, CustPerf $f_{i t}$, we use the FactSet database to identify explicit customers. Only around 12 percent of customers we identify would have been included in industry-size peer groups in previous studies (e.g., Albuquerque 2009, Albuquerque 2013), suggesting that the customer RPE that we examine is distinct from what these studies would observe. That is, they belong in the same 2-digit SIC code industry and size quartile as the firm. Recall that we create distinct sets of industry peer and customer peer groups to use in our analyses by removing any overlap. The average duration of customer relationships in our sample is 783 days.

\section{<Insert Table 2 about here>}

Table 3 provides the Pearson correlation table for our sample. CEO pay (CEOPay $\left.{ }_{i t}\right)$ is negatively associated with customer performance $\left(\operatorname{CustPer} f_{i t}\right)$, as well as peer performance $\left(\operatorname{PeerPerf}_{i t}\right)$. Firm performance $\left(\right.$ FirmPerf $\left._{i t}\right)$ is positively associated with customer 
performance (CustPerf $f_{i t}$ ), consistent with the prior literature (Cohen and Frazzini 2008) and in support of the potential value of customer performance in customer RPE. Firm performance $\left(\right.$ FirmPerf $\left._{i t}\right)$ is also positively correlated with peer performance $\left(\operatorname{PeerPerf}_{i t}\right)$ and market performance $\left(\operatorname{MktPerf}_{i t}\right)$, consistent with the value of each as the basis of industry peer RPE as documented in prior research (e.g. Jayaraman et al. 2018).

\section{<Insert Table 3 about here $>$}

\subsection{Test of hypothesis $\mathrm{H1}$}

Table 4 presents the test of hypothesis H1 which predicts the use of customer RPE, indicated by a negative association between CEO total compensation and customer performance. Model 1 in Table 4 tests for this relation in the absence of industry peer RPE. Model 2, the estimation of equation (1), adds peer performance as a means of testing for customer RPE incremental to industry peer RPE documented in prior research. In Model 3, as a robustness test, we add a measure of market performance.

In all models, the coefficients on FirmPerf $f_{i t}$ are positive and significant $(0.059,0.065$, and 0.076 , respectively, all $\mathrm{p}<0.01$ ). This positive association between firm performance and CEO compensation is as expected and reflects CEO pay-for-performance. Consistent with our hypothesis $\mathrm{H} 1$, CustPerf $_{i t}$ is negative and significant $(-0.058, \mathrm{p}<0.05)$ in Model 1, indicating that firms not only use own-performance when setting CEO compensation, but also use customer performance to filter out shocks transmitted from customers. Importantly, this result holds after controlling for PeerPerfit (Model 2) and for MktPerfit (Model 3), indicating that the riskfiltering effect of customer-relative performance evaluation (customer RPE) is incremental to that of RPE using industry-size peers or market index performance documented in prior studies (Albuquerque 2009, Albuquerque 2013). 
In terms of economic significance, Model 3 indicates that a $10 \%$ increase in focal firm return leads to approximately a $0.73 \%$ increase in total CEO compensation (i.e., an increase in compensation of $\$ 42.01 \mathrm{~K}$ at mean levels of CEO compensation). Offsetting this increase in compensation, however, are adjustments to account for customer, peer, and market returns. A 10\% increase in customer return (e.g., $14 \%$ to $15.4 \%$ ) leads to approximately a $0.50 \%(\$ 29.11 \mathrm{~K})$ decrease in total CEO compensation, and a $10 \%$ increase in industry peer firm return leads to approximately a $0.78 \%(\$ 45.14 \mathrm{~K})$ decrease in total CEO compensation. ${ }^{6}$ Thus, customer RPE has an economically significant effect on total CEO compensation as compared to the effects on compensation of industry peer stock return performance and the firm's own stock return performance.

In untabulated analyses, we find that these results also hold at a 5\% significance level (10\% significance level) after including firm-fixed (CEO-fixed) effects which control for firm-specific (CEO-specific) time-invariant factors that may influence CEO compensation (e.g., corporate governance attributes, CEO ability, CEO career opportunities).

\section{<Insert Table 4 about here>}

\subsection{Test of hypothesis $\mathrm{H} 2 \mathrm{a}$}

If the documented negative association between CEO pay and customer performance (H1) is driven by the firm's motive to filter out exogenous noise, theory (e.g. Holmstrom 1982) predicts that this association will be stronger when the firm shares more noise with its customers. Thus, $\mathrm{H} 2 \mathrm{a}$ predicts that the negative association between focal firm and customer performance will be larger in magnitude when the focal firm and customer performance tend to comove.

\section{<Insert Table 5 about here>}

\footnotetext{
${ }^{6} \mathrm{~A} 10 \%$ increase in market-wide returns is associated with a reduction in CEO total compensation of $2.18 \%$ $(\$ 126.12 \mathrm{k})$.
} 
Table 5, Model 1 provides the estimation of equation (2) and the test of H2a. Consistent with results reported in Table 4, the incentive weight on focal firm performance is positive $(0.055$, $\mathrm{p}<0.01)$. As predicted in $\mathrm{H} 2 \mathrm{a}$, the coefficient on $\operatorname{CustPerf}_{i t} * \operatorname{Corr}_{i \text {, }}$, the interaction between customer performance and the firm-customer return correlation, is negative and significant (-0.154, $\mathrm{p}<0.05)$. This indicates that firms put a larger negative weight on customer performance when common variation is higher. Note that the coefficient on CustPerfit is insignificant at conventional levels $(\mathrm{p}<0.10$, one-tailed).

\subsubsection{H2a supplemental analysis: Sales volatility}

As a robustness test, we substitute for the firm-customer return correlation variable a measure of focal firm sales volatility, Salevolit, measured as the standard deviation of focal firm sales from year t- 4 to t. To the extent that the focal firm's sales volatility is transferred from its customers, we would expect to see increased use of customer RPE - i.e., we would expect a negative association between $\mathrm{CEO}$ total and compensation and customer performance to be larger in magnitude. Table 5, Model 2 presents the results of our test of this expectation. As expected, we find a negative coefficient on $\operatorname{CustPerf}_{i t} *$ Salevol $_{i t}(-0.302, \mathrm{p}<0.05)$. This provides additional support for our conclusion that firms are using customer performance as a means of filtering noise from CEO performance measures.

\subsubsection{H2a supplemental analysis: Product specialization}

As supplemental evidence to further corroborate our evidence in support of $\mathrm{H} 2 \mathrm{a}$, we examine whether firms that offer more specialized products or services use customer RPE to a greater extent. These firms are more likely to be tied to their customers at least in the short-run, and thus are less able to evade the shocks due to changes in customer demands. We use the level of $\mathrm{R} \& \mathrm{D}$ expenses divided by total book value of assets $\left(R \& D_{i t}\right)$ as our first proxy for product 
specialization, where we assume that the expense is zero if the CEO-year observation has missing R\&D expenses. ${ }^{7}$ The second (inverse) proxy for product specialization we use is the product similarity measure developed by Hoberg and Phillips (2016) $\left(\operatorname{Simm}_{i t}\right) .{ }^{8}$ Hoberg and Phillips (2016) calculate pairwise product similarity scores between firms in the CRSP/Compustat universe through textual analysis of product descriptions from firms' annual $10-\mathrm{K}$ filings. Using these scores, they construct the Text-based Network Industry Classification (TNIC) for each firm, which classifies firms into product similarity "industries." The product similarity measure we use is the total similarity score for the focal firm's TNIC industry from the Hoberg and Phillips' Data Library. ${ }^{9}$ This measure captures the degree of product similarity of the firms in the focal firm's TNIC industry and is, thus, an inverse proxy for product specialization that is expected to result in a weaker (less negative) incentive weight on customer performance.

\section{<Insert Table 6 about here>}

Table 6 presents the results of an OLS model in which we include interactions between customer performance $\left(\right.$ CustPerf $\left._{i t}\right)$ and each of $R \& D_{i t}$ (Model 1) and Simmit (Model 2). We do not find statistically significant (at conventional levels) evidence that firms with higher levels of R\&D put a smaller negative weight on customer performance $(-0.211, \mathrm{p}<0.10$, one-tailed). We find evidence that firms with higher levels of product similarity with other firms in their TNIC industry put a smaller negative weight (i.e., positive coefficient on the interaction term, CustPerf $_{i t} * \operatorname{Simm}_{i t}$ ) on customer performance $(0.008, \mathrm{p}<0.10)$. Taken together, we provide marginal support for the expectation that firms use customer RPE to a greater extent when their products and services are

\footnotetext{
${ }^{7}$ R\&D expenses has also been used as a crude measure of customer-relationship specific investments (Raman and Shahrur 2008), consistent with our argument that firms with high R\&D expenses are more likely to be tied to their customers.

${ }^{8}$ This measure is based on the similarity score generated by parsing the product descriptions from firm 10-Ks. More description is available at http://hobergphillips.tuck.dartmouth.edu/idata/Readme_tnic3HHIData.txt.

${ }^{9}$ http://hobergphillips.tuck.dartmouth.edu/
} 
more specialized and thus more likely tailored to their customers in the short-run.

\subsubsection{H2a supplemental analysis: Cost elasticity}

Lastly, we examine whether focal firms that have more cost elasticity that allows them to more readily adapt to demand shocks have less need for the use of customer RPE - i.e., they have a weaker negative relation between customer performance and CEO total compensation. Cost elasticity with respect to sales measures refers to the percent variation in costs for a given percent variation in sales. High cost elasticity indicates a cost structure with low fixed costs relative to variable costs (i.e., low operating leverage), while low cost elasticity indicates a cost structure with high fixed costs relative to variable costs (i.e., high operating leverage). Low operating leverage firms are exposed to lower performance risk from demand fluctuations.

We use two measures of cost elasticity. First, we compute the focal firm's elasticity of selling, general, and administrative expenses $\left(S G \&\right.$ Aelasticity $\left._{i t}\right)$, defined as the change in logged SG\&A expenses in response to change in logged sales from year t-1 to year t. Higher elasticity in SG\&A expenses indicates a focal firm's ability to scale back customer-related service expenses as needed and has been shown to reflect a lower level of customer-relationship-specific investments (Irvine et al. 2016). Second, borrowing from the cost rigidity measure in previous studies (Anderson et al. 2003, Irvine et al. 2016), we compute the focal firm's elasticity of cost of goods sold (COGSelasticity (CO $_{\text {) }}$, defined as the change in logged COGS expenses in response to change in logged sales from year $\mathrm{t}-1$ to year $\mathrm{t}$.

\section{<Insert Table 7 about here>}

Table 7 presents the results of an OLS model in which we include interactions between customer performance (CustPerf it $_{\text {) }}$ and each of SG\&Aelasticity (Model 1) and COGSelasticity $_{i t}$ (Model 2). Results suggest that firms with higher SG\&A elasticity place a smaller negative weight 
on customer performance (coefficient on the $\operatorname{CustPerf}_{i t} * S G \&$ Aelasticity ${ }_{i t}$ interaction of 0.244 , $\mathrm{p}<0.10)$. Results also suggest that firms with higher COGS elasticity place a smaller negative weight on customer performance (coefficient on the $\operatorname{CustPerf}_{i t} *{ }^{*}$ OGSelasticity $i t$ interaction of $0.100, \mathrm{p}<0.10)$. We thus provide support for the expectation that firms with greater cost elasticity make less use of customer RPE.

\subsection{Test of hypothesis H2b}

Although using customer RPE has the benefit of insulating demand shocks, this practice can also motivate the CEO to take strategic actions (e.g., price gouging) harmful to the long-term relationship with the customer and, ultimately, harmful to long-term firm value. Assuming that customer RPE is implemented with these potential adverse effects in mind, Hypothesis H2b predicts that customer performance is less likely to be used in incentive contracting if customer relationships have higher economic value to the firm.

\section{<Insert Table 8 about here>}

Table 8 presents the results of an OLS model of equation (3) in which we include interactions between customer performance (CustPerfit) and each of our proxies of customer relationship value: CC_Rankit (our measure of increased customer relationship value from customer base concentration, consistent with Patatoukas 2011) (Model 1) and F_duration ${ }_{i t}$ (the measure of future customer relationship duration) (Model 2). As predicted by $\mathrm{H} 2 \mathrm{~b}$, we find a positive coefficient on $C C_{-} \operatorname{Rank}_{i t}(0.022, \mathrm{p}<0.05)$ indicating firms make less use of customer RE when the firm has higher customer-base concentration.

This result is in contrast to our previous result that firms with more specialized products make greater use of customer RPE. When stronger ties are due to high customer concentration, customers are likely to have higher market power over the firm. The focal firm has a higher need 
to avoid the adverse CEO incentives to engage in aggressive strategic interactions with the customer that may harm the relationship. This leads to a reduction in the use of customer RPE (consistent with the documented positive coefficient on CustPerf ${ }_{i t}{ }^{*} C C_{-}$Rank $_{i t}$ in Table 8, Model 1). By contrast, when stronger ties are due to the focal firm's product specialization, the focal firm is likely to have higher market power. Where the focal firm has market power from specialized products, the risk of the loss of the customer is lower and concern for excessive strategic interactions is reduced. The focal firm is thus more likely to use customer RPE and reap the benefits of a more efficient CEO compensation contract (consistent with the documented negative coefficient on CustPerfit $_{i t} R \& D_{i t}$ in Table 6, Model 1).

Table 8, Model 2 confirms that, as expected and consistent with $\mathrm{H} 2 \mathrm{~b}$, firms are less likely to use customer performance in incentive contracting when the relationship with customers has a higher average future duration ( $F_{-}$duration $\left._{i t}\right)$. Specifically, the coefficient on the CustPerf $_{i t} * F_{\text {duration }}$ it interaction variable is positive $(3.56 \mathrm{e}-5, \mathrm{p}<0.10)$.

\section{<Insert Table 9 about here>}

\subsection{Supplemental analysis: Active and inactive relationships}

A potential concern of our analysis is that customer selection is partly an endogenous decision of a firm. If the firm is more likely to trade with a customer who is in the same geographic area, shares the same technology, or uses the same materials, the firm and its customer are likely to share common shocks stemming from these similarities. If the firm insulates CEO compensation from these shocks by putting a negative weight on the common shocks themselves, CEO compensation could be negatively correlated with customer performance even when the firm does not necessarily implement customer RPE. To mitigate this concern, we test if the negative association between CEO total compensation and customer performance holds for customer 
relationships that had just ended in year $\mathrm{t}-1$ or that would just start in year $\mathrm{t}+1 .{ }^{10}$ If the results are driven by firms' placing a negative weight on common shocks rather than on customer performance, the associated relation should also be found in periods before the customer relation begins or after it ends. Results in Table 8 demonstrate that the significant association is only found for active relationships, and not for recently ended or forthcoming inactive relationships. This suggests the negative association between CEO total compensation and customer performance we document is likely due to customer RPE and not driven by correlated omitted variables.

\subsection{Supplemental analysis: Natural disasters to customer headquarters}

Another potential concern is that part of customer performance may be related to CEO efforts, and thus, not exogenous. Although this concern biases against finding a negative coefficient on customer returns, we examine major natural disasters to customer headquarters to identify exogenous demand shocks. Following Barrot and Saugasgnat (2016), we gather natural disaster data from SHELDUS (Spatial Hazard and Loss Database for the United States). We restrict the sample of disasters to those lasting less than 30 days and causing estimated damages above 1 billion dollars. We posit that major natural disasters to customers will generate negative demand shocks to the firm that are exogenous to CEO efforts. ${ }^{11}$

As Barrot and Saugasgnat (2016) finds that natural disaster shocks through year t-3 to supply chain partners (suppliers in their study) has a significantly negative effect to firm performance in year t, we define CustShock ${ }_{i t}$ as 1 if any firm in the customer peer group has experienced a natural disaster from year t-3 to year t. About $3 \%$ of our observations has had a natural disaster happen to one of their customers in year $\mathrm{t}$, and about $11 \%$ has had a natural

\footnotetext{
${ }^{10}$ Requiring the firm-year observations to have both sets of customer relationships that had ended specifically in $t-1$ and that would start specifically in $\mathrm{t}+1$ leads to a large loss of observations.

${ }^{11}$ In untabulated analyses, we find that natural disasters to customer headquarters is associated with significant negative effects on customer returns for that year.
} 
disaster happen to one of their customers between in year $\mathrm{t}-3$ and year t. Consistent with our expectation that natural disasters to customer firms creates a negative exogenous shock that should be filtered out from CEO compensation, the coefficient on CustShock ${ }_{i t}$ is positive and significant.

\section{<Insert Table 10 about here>}

\section{CONCLUSION}

We examine whether firms use customer performance in evaluating CEO performance, a practice we call "customer relative performance evaluation" (customer RPE). We propose that firms use customer performance in addition to industry peer performance and market indices to filter out common performance shocks specific to the customer-supplier relation. Theory (Homstrom 1982) predicts that doing so improves the efficiency of CEO contracting.

Using Supply Chain Relationship data provided by FactSet, we compute a measure of customer performance for the specific customers comprising a firm's customer base. Consistent with our prediction, we find a significant negative association between CEO total compensation and customer performance indicative of the use of customer RPE. In additional tests, we find that the negative incentive weight on customer performance is larger in magnitude when the focal firm is more vulnerable to shocks in demand transferred from the downstream customer. Specifically, the negative incentive weight is larger when focal firm performance is more highly correlated with customer performance, when focal firm sales are more volatile, and when the focal firm's products/services are less standardized. On the other hand, the negative weight is smaller when the firm has high cost elasticity that buffer its performance from demand shocks. Lastly, we present evidence that customer RPE is designed with the possible adverse effects of incentives for the 
CEO to engage in excessive strategic behavior with the customer. We predict that the use of customer RPE will be less pronounced when the value of customer relationships is higher. Consistent with our expectation, we find that the negative incentive weight on customer performance is smaller in magnitude when customer profitability (as proxied by customer concentration) is higher and when the future duration of customer relationships are longer.

While there is extensive prior research examining the use of industry peer RPE, we are the first study to document the use of customer performance in relative performance evaluation. Demand shocks emanating from a firms specific customer base can expose a firm to significant performance risk - risk that is often times not imposed on the firms industry peers who do not have a relationship with that customer and, hence, not able to be filtered from firm performance measures using industry peer RPE. Absent customer RPE, firm performance risk translates to greater compensation risk and, in turn, larger compensation risk premium that must be paid to the CEO. Our study provides the first empirical evidence that contracting efficiency is restored through the use of customer RPE to filter demand shocks emanating up the supply chain. 


\section{APPENDIX A. Variable Definitions}

\begin{tabular}{|c|c|}
\hline CEOPay $_{i t}$ & $\begin{array}{l}\text { Year } t \log \text { of the sum of the focal firm CEO's: salary, bonus, the fair value of stock } \\
\text { option awards and restricted stock awards (per SFAS 123R), the change in deferred } \\
\text { compensation, non-equity incentive plan compensation, and all other compensation. }\end{array}$ \\
\hline CustPerfit & $\begin{array}{l}\text { Log of } 1 \text { plus equal-weighted average of the annual stock returns of the focal firm's } \\
\text { customers (as identified in the FactSet database) in year t. }\end{array}$ \\
\hline PeerPerfit & $\begin{array}{l}\text { Log of } 1 \text { plus equal-weighted average of annual stock return for year t across all firms in } \\
\text { the Compustat-CRSP merged database that belong in the focal firm's same SIC 2-digit } \\
\text { industry code and size quartile, but not identified as the focal firm's customer from } \\
\text { FactSet database, for year t. }\end{array}$ \\
\hline MktPerfit & Log of 1 plus S\&P 500 market index return for year t ending in fiscal month of firm i. \\
\hline FirmPerfit & Log of 1 plus annual stock return of the focal firm for fiscal year $t$. \\
\hline Corr $_{i t}$ & $\begin{array}{l}\text { Correlation between focal firm annual stock return and average customer annual stock } \\
\text { return from year } \mathrm{t} \text { to } \mathrm{t}-4 \text {. }\end{array}$ \\
\hline CC_Rank it $_{1}$ & Decile rank of the sum of customers' squared sales percentages for year $t$. \\
\hline$F_{-}$duration ${ }_{i t}$ & $\begin{array}{l}\text { The focal firm's average number of days of future customer relationship durations. } \\
\text { Future customer relationship duration is computed for each customer relationship as the } \\
\text { number of days between the first day of year t (or the start-date of the relationship, } \\
\text { whichever comes later), and the end-date of the firm's final relationship with the } \\
\text { customer. }\end{array}$ \\
\hline Vol $_{i t}$ & Focal firm standard deviation of monthly stock returns during year $\mathrm{t}$ \\
\hline$L e v_{i t}$ & Focal firm book value of liability divided by the book value of assets. \\
\hline$B t m_{i t}$ & $\begin{array}{l}\text { Focal firm total assets minus total liabilities, divided by market value of equity for year } \\
\text { t. }\end{array}$ \\
\hline Lnat $_{i t}$ & Value of $\log$ (total assets) for year $t$. \\
\hline Duality $_{i t}$ & $\begin{array}{l}\text { A dummy variable that indicates whether the focal firm CEO serves as the chairman of } \\
\text { the board for year } t \text {. }\end{array}$ \\
\hline LnCEOtenure $_{i t}$ & Log of the full years the focal firm CEO has been in office until year $t$. \\
\hline Firmspecificwealth $h_{i t}$ & $\begin{array}{l}\text { Sum of the value of stock and equity portfolio held by the focal firm CEO, also known } \\
\text { as inside equity, in year } t \text {. }\end{array}$ \\
\hline Salevol $_{i t}$ & Standard deviation of focal firm sales from year $\mathrm{t}$ to $\mathrm{t}-4$. \\
\hline$R \& D_{i t}$ & $\begin{array}{l}\text { Level of focal firm R\&D expenses divided by total book value of assets for year } t \text {, or } \\
\text { zero if } R \& D \text { expenses is missing for the observation. }\end{array}$ \\
\hline $\operatorname{Simm}_{i t}$ & $\begin{array}{l}\text { The total similarity score for the focal firm's TNIC industry gathered from the Hoberg } \\
\text { and Phillips' Data Library. This measure captures the degree of product similarity of the } \\
\text { firms in the focal firm's TNIC industry. TNIC industry classification is based on textual } \\
\text { analysis of } 10 \text {-Ks for year t (Hoberg and Phillips 2016). }\end{array}$ \\
\hline SG\&Aelasticity $_{i t}$ & $\begin{array}{l}\text { Focal firm change in logged SG\&A expenses in response to change in logged sales from } \\
\text { year t- } 1 \text { to year } t \text {. }\end{array}$ \\
\hline COGSelasticity $_{i t}$ & $\begin{array}{l}\text { Focal firm change in logged COGS expenses in response to change in logged sales from } \\
\text { year t- } 1 \text { to year } t \text {. }\end{array}$ \\
\hline CustShock $_{i t}$ & $\begin{array}{l}1 \text { if one of the customers has experienced a major natural disaster from year } \mathrm{t}-3 \text { to year } \mathrm{t} \text {, } \\
0 \text { otherwise. }\end{array}$ \\
\hline
\end{tabular}




\section{REFERENCES}

Aiken, L. S., and S. G. West. 1991. Multiple Regression: Testing and Interpreting Interactions. London, U.K.: Sage Publications.

Aggarwal, R. K., and A. A. Samwick. 1999. Executive compensation, strategic competition, and relative performance evaluation: Theory and evidence. The Journal of Finance 54(6): 1999-2043.

Albuquerque, A. 2009. Peer firms in relative performance evaluation. Journal of Accounting and Economics 48(1): 69-89.

Albuquerque, A. M. 2013. Do growth-option firms use less relative performance evaluation? The Accounting Review 89(1): 27-60.

Anderson, M. C., R. D. Banker, and S. N. Janakiraman. 2003. Are selling, general, and administrative costs "sticky"? Journal of Accounting Research 41(1): 47-63.

Antle, R., and A. Smith. 1986. An empirical investigation of the relative performance evaluation of corporate executives. Journal of Accounting Research 24(1): 1-39.

Banker, R. D., and S. M. Datar. 1989. Sensitivity, precision, and linear aggregation of signals for performance evaluation. Journal of Accounting Research 27(1): 21-39.

Bannister, J. W., H. A. Newman, and J. Weintrop. 2011. Tests for relative performance evaluation based on assumptions derived from proxy statement disclosures. Review of Quantitative Finance and Accounting 37(2): 127-148.

Barrot, J.N. and Sauvagnat, J., 2016. Input specificity and the propagation of idiosyncratic shocks in production networks. The Quarterly Journal of Economics 131(3): 1543-1592.Bertrand, M., and S. Mullainathan. 2001. Are CEOs rewarded for luck? The ones without principals are. The Quarterly Journal of Economics 116(3): 901-932.

Black, D., S. Dikolli, and C. Hofmann. 2015. Peer group composition, peer performance aggregation, and detecting relative performance evaluation. Working paper.

Cheng, C. S. A., and J. D. Eshleman, J. D. 2014. Does the market overweight imprecise information? Evidence from customer earnings announcements. Review of Accounting Studies 19(3): 1125-1151.

Cohen, L. and A. Frazzini. 2008. Economic links and predictable returns. The Journal of Finance 63(4): 1977-2011.

Coles, J. L., N. D. Daniel, and L. Naveen. 2006. Managerial incentives and risk-taking. Journal of Financial Economics 79(2): 431-468.

Eshleman, J. D., and P. Guo. 2014. The market's use of supplier earnings information to value customers. Review of Quantitative Finance and Accounting 43(2): 405-422.

Faulkender, M., and J. Yang, J. 2010. Inside the black box: The role and composition of compensation peer groups. Journal of Financial Economics 96(2): 257-270.

Feichter, C., F. Moers, and O. Timmermans. 2019. The effect of peer group overlap in executives' RPE contracts on competitive aggressiveness. Working paper. Available at SSRN 3381072.

Feltham, G. A., and J. Xie. 1994. Performance measure congruity and diversity in multi-task principal/agent relations. The Accounting Review 69(3): 429-453.

Garvey, G. T., and T. T. Milbourn. 2006. Asymmetric benchmarking in compensation: Executives are rewarded for good luck but not penalized for bad. Journal of Financial Economics 82(1): 197-225. 
Gibbons, R., and K. J. Murphy. 1990. Relative performance evaluation for chief executive officers. Industrial and Labor Relations Review 43(3): 30-51.

Gong, G., L. Y. Li, and J. Y. Shin. 2011. Relative performance evaluation and related peer groups in executive compensation contracts. The Accounting Review 86(3): 1007-1043.

Green, J. R., and N. L. Stokey. 1983. A comparison of tournaments and contracts. Journal of Political Economy 91(3): 349-364.

Hall, B. J., and J. B. Liebman. 1998. Are CEOs really paid like bureaucrats? The Quarterly Journal of Economics 113(3): 653-691.

Holmstrom, B. 1982. Moral hazard in teams. The Bell Journal of Economics 13(2): 324-340.

Irvine, P. J., S. S. Park, and C. Y1ldızhan. 2015. Customer-base concentration, profitability, and the relationship life cycle. The Accounting Review 91(3): 883-906.

Jayaraman, S., T. T. Milbourn, F. S. Peters, and H. Seo. 2018. Product market peers and relative performance evaluation. Working paper.

Jenter, D., and F. Kanaan. 2015. CEO turnover and relative performance evaluation. Journal of Finance 70(5): 2155-2184.

Lazear, E. P., and S. Rosen. 1981. Rank-order tournaments as optimum labor contracts. Journal of Political Economy 89(5): 841-864.

Murphy, K. J. 2000. Performance standards in incentive contracts. Journal of Accounting and Economics 30(3): 245-278.

Olsen C., and J. R. Dietrich. 1985. Vertical information transfers - the association between retailer's sales announcements and supplier's security returns. Journal of Accounting Research 23: 144-166.

Patatoukas, P. N. 2011. Customer-base concentration: Implications for firm performance and capital markets. The Accounting Review 87(2): 363-392.

Raman, K., and H. Shahrur. 2008. Relationship-specific investments and earnings management: Evidence on corporate suppliers and customers. The Accounting Review 83(4): 1041-1081.

Rajgopal, S., T. Shevlin, and V. Zamora. 2006. CEOs' outside employment opportunities and the lack of relative performance evaluation in compensation contracts. Journal of Finance 61(4): 1813-1844.

Vrettos, D. 2013. Are relative performance measures in CEO incentive contracts used for risk reduction and/or for strategic interaction? The Accounting Review 88 (6): 2179-2212.

Wu, M. G. 2014. Common vs. firm-specific risks in relative performance evaluation. Working paper.

Wu, M. G. 2018. Optimal risk trade-off in relative performance evaluation. Journal of Management Accounting Research 31(1): 247-259. 
TABLE 1

Sample Selection

All CEO-year observations from 2003 to 2018 from Execucomp

31,087

Less:

Observations without CEO compensation data from Execucomp

198

Observations without customer relationship data from FactSet

17,108

Observations with insufficient data for control variables

1,998

Observations where the CEO was not in the office for the entire year $t$

Total CEO-year observations used in the main analysis

11,662

TABLE 2

Descriptive Statistics

\begin{tabular}{|c|c|c|c|c|c|c|}
\hline Variables & $\mathbf{N}$ & Mean & SD & 1st Qrt. & Median & 3rd Qrt. \\
\hline CEOPay $_{i t}($ Raw $)$ & 11,662 & $5,793.20$ & $5,777.40$ & $1,936.46$ & $4,034.22$ & $7,501.90$ \\
\hline CEOPay $_{i t}$ & 11,662 & 8.23 & 0.98 & 7.57 & 8.30 & 8.92 \\
\hline CustPerf $_{i t}($ Raw) & 11,662 & 0.14 & 0.31 & -0.01 & 0.13 & 0.27 \\
\hline CustPerf $_{i t}$ & 11,662 & 0.10 & 0.27 & -0.01 & 0.12 & 0.24 \\
\hline $\operatorname{PeerPerf}_{i t}($ Raw $)$ & 11,662 & 0.13 & 0.26 & -0.01 & 0.12 & 0.27 \\
\hline PeerPerf & 11,662 & 0.10 & 0.24 & -0.01 & 0.12 & 0.24 \\
\hline $\operatorname{MktPerf}_{i t}($ Raw) & 11,662 & 0.09 & 0.15 & 0.03 & 0.11 & 0.16 \\
\hline MktPerf ${ }_{i t}$ & 11,662 & 0.07 & 0.16 & 0.03 & 0.11 & 0.15 \\
\hline FirmPerf $_{i t}($ Raw $)$ & 11,662 & 0.16 & 0.48 & -0.12 & 0.11 & 0.34 \\
\hline FirmPerf $_{i t}$ & 11,662 & 0.07 & 0.41 & -0.12 & 0.11 & 0.30 \\
\hline Corr $_{i t}$ & 6,913 & 0.42 & 0.47 & 0.12 & 0.55 & 0.80 \\
\hline Salevol $_{i t}$ & 10,439 & 0.16 & 0.16 & 0.06 & 0.11 & 0.20 \\
\hline$R \& D_{i t}$ & 9,462 & 0.07 & 0.14 & 0.00 & 0.01 & 0.10 \\
\hline $\operatorname{Simm}_{i t}$ & 9,462 & 3.73 & 4.79 & 1.27 & 1.97 & 3.92 \\
\hline SG\&Aelasticity $_{i t}$ & 10,344 & 0.07 & 0.16 & -0.01 & 0.06 & 0.14 \\
\hline COGSelasticity $_{i t}$ & 10,344 & 0.07 & 0.24 & -0.02 & 0.07 & 0.16 \\
\hline$C C_{i t}$ & 4,579 & 0.07 & 0.11 & 0.01 & 0.03 & 0.07 \\
\hline$F_{\text {_duration }}{ }_{i t}$ & 4,579 & $1,760.16$ & $1,188.18$ & 861.17 & $1,500.00$ & $2,412.00$ \\
\hline$V_{o l} l_{i t}$ & 11,662 & 0.10 & 0.06 & 0.06 & 0.09 & 0.13 \\
\hline$L e v_{i t}$ & 11,662 & 0.52 & 0.24 & 0.35 & 0.52 & 0.67 \\
\hline Btm $_{i t}$ & 11,662 & 0.50 & 0.42 & 0.25 & 0.42 & 0.65 \\
\hline Lnat $_{i t}$ & 11,662 & 7.62 & 1.67 & 6.44 & 7.53 & 8.70 \\
\hline Duality $_{i t}$ & 11,662 & 0.50 & 0.50 & 0.00 & 1.00 & 1.00 \\
\hline LnCEOtenure $_{i t}$ & 11,662 & 1.67 & 0.91 & 1.10 & 1.79 & 2.30 \\
\hline Firmspecificwealth $_{i t}$ & 11,662 & $52,983.01$ & $139,601.50$ & $6,560.84$ & $16,357.35$ & $43,611.99$ \\
\hline CustShock $_{i t}$ & 11,654 & 0.11 & 0.31 & 0 & 0 & 0 \\
\hline
\end{tabular}


TABLE 3

Correlations

\begin{tabular}{|c|c|c|c|c|c|c|c|c|c|c|c|c|c|}
\hline & & 1 & 2 & 3 & 4 & 5 & 6 & 7 & 8 & 9 & 10 & 11 & 12 \\
\hline 1 & CEOPay $_{i t}$ & 1 & & & & & & & & & & & \\
\hline 2 & CustPerfit & -0.029 & 1 & & & & & & & & & & \\
\hline 3 & PeerPerf $_{i t}$ & -0.038 & 0.625 & 1 & & & & & & & & & \\
\hline 4 & MktPerf $_{i t}$ & -0.001 & 0.606 & 0.701 & 1 & & & & & & & & \\
\hline 5 & FirmPerf $_{i t}$ & 0.056 & 0.448 & 0.528 & 0.52 & 1 & & & & & & & \\
\hline 6 & Vol $_{i t}$ & -0.298 & -0.032 & -0.021 & -0.173 & -0.098 & 1 & & & & & & \\
\hline 7 & $\operatorname{Lev}_{i t}$ & 0.285 & -0.039 & -0.039 & -0.03 & -0.07 & -0.006 & 1 & & & & & \\
\hline 8 & Btm $_{i t}$ & -0.184 & -0.166 & -0.193 & -0.186 & -0.364 & 0.198 & -0.204 & 1 & & & & \\
\hline 9 & Lnat $_{i t}$ & 0.721 & -0.024 & -0.029 & 0.003 & 0.012 & -0.368 & 0.417 & -0.025 & 1 & & & \\
\hline 10 & Duality $_{i t}$ & 0.143 & 0.041 & 0.043 & $\mathbf{0 . 0 3}$ & 0.038 & -0.093 & 0.079 & -0.013 & 0.178 & 1 & & \\
\hline 11 & LnCEOtenure $_{i t}$ & -0.033 & 0.011 & 0.003 & 0.006 & 0.004 & -0.012 & -0.11 & 0.009 & -0.075 & 0.311 & 1 & \\
\hline 12 & Firmspecificwealth $_{i t}$ & 0.149 & 0.034 & 0.042 & 0.035 & 0.09 & -0.117 & -0.022 & -0.133 & 0.206 & 0.129 & 0.227 & 1 \\
\hline
\end{tabular}

Bold indicates significance at $\mathrm{p}<0.05$ 
TABLE 4

Customer Relative Performance Evaluation (Test of hypothesis H1)

\begin{tabular}{|c|c|c|c|c|}
\hline \multirow[b]{2}{*}{ Variables } & \multirow[b]{2}{*}{ Prediction } & \multicolumn{3}{|c|}{ Dependent variable: $C E O P a y_{i t}$} \\
\hline & & Model 1 & Model 2 & Model 3 \\
\hline \multirow[t]{2}{*}{ CustPerfit } & $-(\mathrm{H} 1)$ & $-0.058 * *$ & $-0.051 *$ & $-0.053^{*}$ \\
\hline & & $(-2.147)$ & $(-1.889)$ & $(-1.961)$ \\
\hline \multirow[t]{2}{*}{ PeerPerfit } & - & & $-0.077^{*}$ & $-0.082 *$ \\
\hline & & & $(-1.779)$ & $(-1.880)$ \\
\hline \multirow[t]{2}{*}{ MktPerfit } & - & & & $-0.231 * * *$ \\
\hline & & & & $(-2.887)$ \\
\hline \multirow[t]{2}{*}{ FirmPerf ${ }_{i t}$} & + & $0.059 * * *$ & $0.065 * * *$ & $0.076 * * *$ \\
\hline & & $(2.930)$ & $(3.189)$ & $(3.560)$ \\
\hline \multirow[t]{2}{*}{ Vol $_{i t}$} & & 0.148 & 0.157 & 0.122 \\
\hline & & $(0.821)$ & $(0.875)$ & $(0.672)$ \\
\hline \multirow[t]{2}{*}{$L e v_{i t}$} & & $-0.184 * * *$ & $-0.184 * * *$ & $-0.181 * * *$ \\
\hline & & $(-3.324)$ & $(-3.321)$ & $(-3.253)$ \\
\hline \multirow[t]{2}{*}{$B t m_{i t}$} & & $-0.344 * * *$ & $-0.345 * * *$ & $-0.343 * * *$ \\
\hline & & $(-12.213)$ & $(-12.239)$ & $(-12.175)$ \\
\hline \multirow[t]{2}{*}{ Lnat $_{i t}$} & & $0.456 * * *$ & $0.456 * * *$ & $0.456 * * *$ \\
\hline & & $(48.688)$ & $(48.694)$ & $(48.565)$ \\
\hline \multirow[t]{2}{*}{ Duality $_{i t}$} & & $0.043^{*}$ & $0.043 *$ & $0.043^{*}$ \\
\hline & & $(1.930)$ & (1.919) & $(1.927)$ \\
\hline \multirow[t]{2}{*}{ LnCEOtenure $_{i t}$} & & $0.020 *$ & $0.021 *$ & $0.020 *$ \\
\hline & & $(1.775)$ & $(1.787)$ & $(1.776)$ \\
\hline \multirow[t]{2}{*}{ Firmspecificwealth $_{i t}$} & & $-0.000^{*}$ & $-0.000^{*}$ & $-0.000^{*}$ \\
\hline & & $(-1.937)$ & $(-1.940)$ & $(-1.951)$ \\
\hline \multirow[t]{2}{*}{ Constant } & & $4.741 * * *$ & $4.764 * * *$ & $4.819 * * *$ \\
\hline & & $(40.038)$ & $(39.593)$ & $(39.197)$ \\
\hline Observations & & 11,662 & 11,662 & 11,662 \\
\hline R-squared & & 0.604 & 0.604 & 0.604 \\
\hline Year FE & & Yes & Yes & Yes \\
\hline Industry FE & & Yes & Yes & Yes \\
\hline Cluster & & Firm & Firm & Firm \\
\hline Number of Clusters & & 1,735 & 1,735 & 1,735 \\
\hline
\end{tabular}


TABLE 5

The Effect of Common Noise on Customer RPE (Test of hypothesis H2a)

\begin{tabular}{|c|c|c|c|}
\hline \multirow[b]{2}{*}{ Variables } & \multirow[b]{2}{*}{ Prediction } & \multicolumn{2}{|c|}{ Dependent variable: $C E O P a y_{i t}$} \\
\hline & & Model 1 & Model 2 \\
\hline CustPerfit & - & $\begin{array}{l}-0.048 \\
(-1.476)\end{array}$ & $\begin{array}{c}-0.042 \\
(-1.522)\end{array}$ \\
\hline Corrit $_{i t}$ & & $\begin{array}{l}0.047 * * \\
(2.014)\end{array}$ & \\
\hline CustPerf $_{i t} *$ Corr $_{i t}$ & $-(\mathrm{H} 2 \mathrm{a})$ & $\begin{array}{l}-0.154 * * \\
(-2.561)\end{array}$ & \\
\hline Salevol $_{i t}$ & & & $\begin{array}{l}0.154 * * \\
(2.417)\end{array}$ \\
\hline CustPerf $_{i t} *$ Salevol $_{i t}$ & - & & $\begin{array}{l}-0.302 * * \\
(-2.579)\end{array}$ \\
\hline FirmPerfit & & $\begin{array}{l}0.055^{* *} \\
(2.249)\end{array}$ & $\begin{array}{l}0.069 * * * \\
(3.336)\end{array}$ \\
\hline PeerPerfit & & $\begin{array}{l}-0.053 \\
(-1.106)\end{array}$ & $\begin{array}{l}-0.052 \\
(-1.155)\end{array}$ \\
\hline Vol $_{i t}$ & & $\begin{array}{c}0.301 \\
(1.531)\end{array}$ & $\begin{array}{c}0.204 \\
(1.136)\end{array}$ \\
\hline$L e v_{i t}$ & & $\begin{array}{l}-0.127^{* *} \\
(-1.969)\end{array}$ & $\begin{array}{l}-0.159 * * * \\
(-2.814)\end{array}$ \\
\hline$B t m_{i t}$ & & $\begin{array}{l}-0.290 * * * \\
(-9.438)\end{array}$ & $\begin{array}{l}-0.321 * * * \\
(-11.466)\end{array}$ \\
\hline Lnat $_{i t}$ & & $\begin{array}{c}0.455^{* * * *} \\
(42.759)\end{array}$ & $\begin{array}{c}0.457 * * * \\
(45.795)\end{array}$ \\
\hline Duality $_{i t}$ & & $\begin{array}{c}-0.015 \\
(-0.588)\end{array}$ & $\begin{array}{c}0.030 \\
(1.342)\end{array}$ \\
\hline LnCEOtenure $_{i t}$ & & $\begin{array}{l}0.034 * * \\
(2.560)\end{array}$ & $\begin{array}{c}0.023^{*} \\
(1.958)\end{array}$ \\
\hline Firmspecificwealth $_{i t}$ & & $\begin{array}{c}0.000 \\
(1.274)\end{array}$ & $\begin{array}{l}-0.000 \\
(-1.544)\end{array}$ \\
\hline Constant & & $\begin{array}{l}4.586 * * * \\
(23.259)\end{array}$ & $\begin{array}{l}4.849 * * * \\
(40.965)\end{array}$ \\
\hline Observations & & 6,913 & 10,439 \\
\hline R-squared & & 0.651 & 0.622 \\
\hline Year FE & & Yes & Yes \\
\hline Industry FE & & Yes & Yes \\
\hline Cluster & & Firm & Firm \\
\hline Number of Clusters & & 1,175 & 1,625 \\
\hline
\end{tabular}


TABLE 6

The Effect of Product Specialization on Customer RPE

\begin{tabular}{|c|c|c|c|}
\hline \multirow[b]{2}{*}{ Variables } & \multirow[b]{2}{*}{ Prediction } & \multicolumn{2}{|c|}{ Dependent variable: $C E O P a y_{i t}$} \\
\hline & & Model 1 & Model 2 \\
\hline CustPerfit & - & $\begin{array}{c}-0.034 \\
(-1.143)\end{array}$ & $\begin{array}{c}-0.030 \\
(-0.984)\end{array}$ \\
\hline$R \& D_{i t}$ & & $\begin{array}{l}0.415^{* * *} \\
(4.831)\end{array}$ & \\
\hline CustPerfit $* R \& D_{i t}$ & - & $\begin{array}{l}-0.211 \\
(-1.565)\end{array}$ & \\
\hline $\operatorname{Simm}_{i t}$ & & & $\begin{array}{l}0.011 \text { *** } \\
(3.922)\end{array}$ \\
\hline CustPerfit ${ }^{*}$ Simm $_{i t}$ & + & & $\begin{array}{l}0.008 * \\
(1.695)\end{array}$ \\
\hline FirmPerf ${ }_{i t}$ & & $\begin{array}{l}0.081 * * * \\
(3.643)\end{array}$ & $\begin{array}{l}0.070 * * * \\
(3.137)\end{array}$ \\
\hline PeerPerfit & & $\begin{array}{l}-0.123 * * \\
(-2.548)\end{array}$ & $\begin{array}{l}-0.115^{* *} \\
(-2.380)\end{array}$ \\
\hline Vol $_{i t}$ & & $\begin{array}{c}0.089 \\
(0.474)\end{array}$ & $\begin{array}{c}0.126 \\
(0.657)\end{array}$ \\
\hline$L e v_{i t}$ & & $\begin{array}{l}-0.201 * * * \\
(-3.428)\end{array}$ & $\begin{array}{l}-0.208 * * * \\
(-3.563)\end{array}$ \\
\hline$B_{t m}$ & & $\begin{array}{l}-0.336 * * * \\
(-10.929)\end{array}$ & $\begin{array}{l}-0.351 * * * \\
(-11.418)\end{array}$ \\
\hline Lnat $_{i t}$ & & $\begin{array}{c}0.472 * * * \\
(48.949)\end{array}$ & $\begin{array}{c}0.468 * * * \\
(49.129)\end{array}$ \\
\hline Duality $_{i t}$ & & $\begin{array}{l}0.070 * * * \\
(3.014)\end{array}$ & $\begin{array}{l}0.065^{* * *} \\
(2.823)\end{array}$ \\
\hline LnCEOtenure $_{i t}$ & & $\begin{array}{c}0.008 \\
(0.613)\end{array}$ & $\begin{array}{c}0.007 \\
(0.555)\end{array}$ \\
\hline Firmspecificwealth $_{i t}$ & & $\begin{array}{l}-0.000 \\
(-1.617)\end{array}$ & $\begin{array}{l}-0.000 \\
(-1.644)\end{array}$ \\
\hline Constant & & $\begin{array}{l}4.648 * * * \\
(45.308)\end{array}$ & $\begin{array}{l}4.697 * * * \\
(46.971)\end{array}$ \\
\hline Observations & & 9,462 & 9,462 \\
\hline R-squared & & 0.608 & 0.608 \\
\hline Year FE & & Yes & Yes \\
\hline Industry FE & & Yes & Yes \\
\hline Cluster & & Firm & Firm \\
\hline Number of Clusters & & 1,617 & 1,617 \\
\hline
\end{tabular}


TABLE 7

The Effect of Operating Flexibility on Customer RPE

\begin{tabular}{|c|c|c|c|}
\hline \multirow[b]{2}{*}{ Variables } & \multirow[b]{2}{*}{ Prediction } & \multicolumn{2}{|c|}{ Dependent variable: $C E O P a y_{i t}$} \\
\hline & & Model 1 & Model 2 \\
\hline \multirow[t]{2}{*}{ CustPerfit } & - & $-0.049 *$ & -0.045 \\
\hline & & $(-1.660)$ & $(-1.518)$ \\
\hline \multirow[t]{2}{*}{ SG\&Aelasticity ${ }_{i t}$} & & $0.265 * * *$ & \\
\hline & & $(5.442)$ & \\
\hline \multirow[t]{2}{*}{ CustPerf $_{i t} * S G \&$ Aelasticity ${ }_{i t}$} & + & $0.244 *$ & \\
\hline & & $(1.830)$ & \\
\hline \multirow[t]{2}{*}{ COGSelasticity $_{i t}$} & & & $0.100 * * *$ \\
\hline & & & $(3.179)$ \\
\hline \multirow[t]{2}{*}{ CustPerf $_{i t} *$ COGSelasticity ${ }_{i t}$} & + & & $0.134 *$ \\
\hline & & & $(1.656)$ \\
\hline \multirow[t]{2}{*}{ FirmPerf ${ }_{i t}$} & & $0.052 * *$ & $0.051 * *$ \\
\hline & & $(2.422)$ & $(2.358)$ \\
\hline \multirow[t]{2}{*}{ PeerPerf $_{i t}$} & & $-0.084 *$ & -0.067 \\
\hline & & $(-1.936)$ & $(-1.539)$ \\
\hline \multirow[t]{2}{*}{ Vol $_{i t}$} & & 0.106 & 0.093 \\
\hline & & $(0.558)$ & $(0.488)$ \\
\hline \multirow[t]{2}{*}{ Levit } & & $-0.151 * *$ & $-0.166 * * *$ \\
\hline & & $(-2.563)$ & $(-2.826)$ \\
\hline \multirow[t]{2}{*}{$B_{t m}$} & & $-0.345 * * *$ & $-0.354 * * *$ \\
\hline & & $(-11.355)$ & $(-11.653)$ \\
\hline \multirow[t]{2}{*}{ Lnat $_{i t}$} & & $0.461 * * *$ & $0.461 * * *$ \\
\hline & & $(48.405)$ & $(48.259)$ \\
\hline \multirow[t]{2}{*}{ Duality $_{i t}$} & & $0.044 *$ & $0.042 *$ \\
\hline & & $(1.923)$ & $(1.838)$ \\
\hline \multirow[t]{2}{*}{ LnCEOtenure $_{i t}$} & & $0.022 *$ & $0.024 * *$ \\
\hline & & $(1.938)$ & $(2.096)$ \\
\hline \multirow[t]{2}{*}{ Firmspecificwealth $_{i t}$} & & $-0.000 * * *$ & $-0.000 * *$ \\
\hline & & $(-2.606)$ & $(-2.535)$ \\
\hline \multirow[t]{2}{*}{ Constant } & & $4.731 * * *$ & $4.741 * * *$ \\
\hline & & $(38.966)$ & $(38.581)$ \\
\hline Observations & & 10,344 & 10,344 \\
\hline R-squared & & 0.614 & 0.613 \\
\hline Year FE & & Yes & Yes \\
\hline Industry FE & & Yes & Yes \\
\hline Cluster & & Firm & Firm \\
\hline Number of Clusters & & 1,571 & 1,571 \\
\hline
\end{tabular}


TABLE 8

The Effect of Customer Relationship Value on Customer RPE (Test of Hypothesis H2b)

\begin{tabular}{|c|c|c|c|}
\hline \multirow[b]{2}{*}{ Variables } & \multirow[b]{2}{*}{ Prediction } & \multicolumn{2}{|c|}{ Dependent variable: CEOPay $_{i t}$} \\
\hline & & Model 1 & Model 2 \\
\hline CustPerfit & - & $\begin{array}{l}-0.070^{*} \\
(-1749)\end{array}$ & $-0.077^{*}$ \\
\hline CC_Rank ${ }_{i t}$ & & $\begin{array}{c}0.008 \\
(1.449)\end{array}$ & \\
\hline CustPerf $_{i t} *$ CC_Rank ${ }_{i t}$ & $+(\mathrm{H} 2 \mathrm{~b})$ & $\begin{array}{l}0.022 * * \\
(2.176)\end{array}$ & \\
\hline$F_{\text {_duration }}$ it & & & $\begin{array}{c}-0.000 \\
(-0.168)\end{array}$ \\
\hline CustPerf $_{i t}{ }^{*} F_{-}$duration ${ }_{i t}$ & $+(\mathrm{H} 2 \mathrm{~b})$ & & $\begin{array}{l}3.56 \mathrm{e}-5^{*} \\
(1.680)\end{array}$ \\
\hline FirmPerfit & & $\begin{array}{c}0.022 \\
(0.774)\end{array}$ & $\begin{array}{c}0.020 \\
(0.707)\end{array}$ \\
\hline PeerPerfit & & $\begin{array}{l}-0.172 * * \\
(-2.444)\end{array}$ & $\begin{array}{l}-0.159 * * \\
(-2.260)\end{array}$ \\
\hline Vol $_{i t}$ & & $\begin{array}{c}0.250 \\
(0.930)\end{array}$ & $\begin{array}{c}0.269 \\
(0.994)\end{array}$ \\
\hline Lev $_{i t}$ & & $\begin{array}{l}-0.245 * * * \\
(-2.988)\end{array}$ & $\begin{array}{l}-0.250 * * * \\
(-3.038)\end{array}$ \\
\hline Btm $_{i t}$ & & $\begin{array}{l}-0.384 * * * \\
(-8.633)\end{array}$ & $\begin{array}{l}-0.387 * * * \\
(-8.698)\end{array}$ \\
\hline Lnat $_{i t}$ & & $\begin{array}{c}0.481^{* * * *} \\
(37.514)\end{array}$ & $\begin{array}{c}0.479^{* * * *} \\
(37.651)\end{array}$ \\
\hline Duality $_{i t}$ & & $\begin{array}{c}0.041 \\
(1.373)\end{array}$ & $\begin{array}{c}0.042 \\
(1.390)\end{array}$ \\
\hline LnCEOtenure $_{i t}$ & & $\begin{array}{c}-0.005 \\
(-0.289)\end{array}$ & $\begin{array}{c}-0.004 \\
(-0.229)\end{array}$ \\
\hline Firmspecificwealth $_{i t}$ & & $\begin{array}{c}0.000 \\
(0.443)\end{array}$ & $\begin{array}{c}0.000 \\
(0.401)\end{array}$ \\
\hline Constant & & $\begin{array}{l}4.749 * * * \\
(33.757)\end{array}$ & $\begin{array}{l}4.778 * * * \\
(34.552)\end{array}$ \\
\hline Observations & & 4,579 & 4,579 \\
\hline R-squared & & 0.613 & 0.613 \\
\hline Year FE & & Yes & Yes \\
\hline Industry FE & & Yes & Yes \\
\hline Cluster & & Firm & Firm \\
\hline Number of Clusters & & 934 & 934 \\
\hline
\end{tabular}


TABLE 9

Active and Inactive Customer Relationships

\begin{tabular}{|c|c|c|c|c|}
\hline \multirow[b]{2}{*}{ Variables } & \multirow[b]{2}{*}{ Prediction } & \multicolumn{3}{|c|}{ Dependent variable: $C E O P a y_{i t}$} \\
\hline & & $\begin{array}{c}\text { Relationship } \\
\text { active in } \\
\text { year } \mathbf{t}\end{array}$ & $\begin{array}{c}\text { Relationship } \\
\text { ended in } \\
\text { year t-1 }\end{array}$ & $\begin{array}{c}\text { Relationship } \\
\text { started in year } \\
t+1\end{array}$ \\
\hline \multirow[t]{2}{*}{ CustPerfit } & - & $-0.190 *$ & 0.007 & -0.079 \\
\hline & & $(-1.653)$ & $(0.116)$ & $(-0.988)$ \\
\hline \multirow[t]{2}{*}{ PeerPerfit } & - & $-0.264 *$ & $-0.289 * *$ & $-0.272 *$ \\
\hline & & $(-1.941)$ & $(-2.105)$ & $(-1.964)$ \\
\hline \multirow[t]{2}{*}{ MktPerfit } & - & -0.130 & -0.117 & -0.124 \\
\hline & & $(-0.394)$ & $(-0.356)$ & $(-0.378)$ \\
\hline \multirow[t]{2}{*}{ FirmPerf $_{i t}$} & + & $0.137 * *$ & $0.129 * *$ & $0.131 * *$ \\
\hline & & $(2.106)$ & $(1.982)$ & $(2.029)$ \\
\hline \multirow[t]{2}{*}{ Vol $_{i t}$} & & 0.865 & $0.888 *$ & $0.880 *$ \\
\hline & & $(1.628)$ & $(1.673)$ & $(1.665)$ \\
\hline \multirow[t]{2}{*}{$L e v_{i t}$} & & -0.243 & $-0.253 *$ & $-0.251 *$ \\
\hline & & $(-1.635)$ & $(-1.747)$ & $(-1.736)$ \\
\hline \multirow[t]{2}{*}{$B_{t m}$} & & $-0.335 * * *$ & $-0.334 * * *$ & $-0.335 * * *$ \\
\hline & & $(-4.175)$ & $(-4.197)$ & $(-4.250)$ \\
\hline \multirow[t]{2}{*}{ Lnat $_{i t}$} & & $0.454 * * *$ & $0.455^{* * *}$ & $0.455^{* * *}$ \\
\hline & & $(22.590)$ & $(22.804)$ & $(22.758)$ \\
\hline \multirow[t]{2}{*}{ Duality $_{i t}$} & & -0.023 & -0.022 & -0.022 \\
\hline & & $(-0.487)$ & $(-0.460)$ & $(-0.461)$ \\
\hline \multirow[t]{2}{*}{ LnCEOtenure $_{i t}$} & & 0.018 & 0.018 & 0.017 \\
\hline & & $(0.695)$ & $(0.694)$ & $(0.660)$ \\
\hline \multirow[t]{2}{*}{ Firmspecificwealth $_{i t}$} & & $0.000 * * *$ & $0.000 * * *$ & $0.000 * * *$ \\
\hline & & $(6.007)$ & $(6.087)$ & $(6.042)$ \\
\hline \multirow[t]{2}{*}{ Constant } & & $4.718 * * *$ & $4.633 * * *$ & $4.667 * * *$ \\
\hline & & $(9.915)$ & $(9.760)$ & $(9.941)$ \\
\hline Observations & & 1,231 & 1,231 & 1,231 \\
\hline R-squared & & 0.639 & 0.638 & 0.638 \\
\hline Year FE & & Yes & Yes & Yes \\
\hline Industry FE & & Yes & Yes & Yes \\
\hline Cluster & & Firm & Firm & Firm \\
\hline Number of Clusters & & 559 & 559 & 559 \\
\hline
\end{tabular}


TABLE 10

Natural Disasters to Customer Headquarters

\begin{tabular}{|c|c|c|}
\hline Variables & Prediction & Dependent variable: $C_{E O P a y_{i t}}$ \\
\hline CustShock $_{i t}$ & + & $\begin{array}{l}0.061 * * \\
(2.495)\end{array}$ \\
\hline FirmPerf $_{i t}$ & + & $\begin{array}{l}0.072 * * * \\
(3.485)\end{array}$ \\
\hline PeerPerfit & - & $\begin{array}{l}-0.101 * * \\
(-2.378)\end{array}$ \\
\hline Vol $_{i t}$ & & $\begin{array}{c}0.170 \\
(0.940)\end{array}$ \\
\hline Lev $_{i t}$ & & $\begin{array}{l}-0.181 * * * \\
(-3.258)\end{array}$ \\
\hline Btm $_{i t}$ & & $\begin{array}{l}-0.338^{* * * *} \\
(-12.196)\end{array}$ \\
\hline Lnat $_{i t}$ & & $\begin{array}{l}0.455^{* * * *} \\
(48.528)\end{array}$ \\
\hline Duality $_{i t}$ & & $\begin{array}{l}0.046 * * \\
(2.060)\end{array}$ \\
\hline LnCEOtenure $_{i t}$ & & $\begin{array}{c}0.022 * \\
(1.871)\end{array}$ \\
\hline Firmspecificwealth $_{i t}$ & & $\begin{array}{l}-0.000^{* *} \\
(-2.029)\end{array}$ \\
\hline Constant & & $\begin{array}{l}4.964 * * * \\
(65.005)\end{array}$ \\
\hline Observations & & 11,654 \\
\hline R-squared & & 0.602 \\
\hline Year FE & & Yes \\
\hline Industry FE & & Yes \\
\hline Cluster & & Firm \\
\hline Number of Clusters & & 1,737 \\
\hline
\end{tabular}

$* * * \mathrm{p}<0.01, * * \mathrm{p}<0.05, * \mathrm{p}<0.10$ 